\title{
DIALOGUE
}

\section{A Year Later}

\section{Jack Hess, GSA Executive Director}

It is an honor for me to report on the great achievements of GSA over the past year. Last year at this time, I attended the Boston Annual Meeting wondering what I had jumped into and what the next year would bring. I am pleased to say that despite many challenges, in many aspects GSA stands stronger today than at any other time in its history. Financially, we are still not out of the woods, but I do see a path forward. We have taken and are continuing to take many steps to help bring our financial situation under control.

GSA has seen positive membership growth for the seventh year in a row, more members have participated in Society and Division elections than in the past few years, the annual meeting was a great success, and our publications thrive. Additionally, our Education and Outreach programs experienced great success, and we continue to strengthen our relationships with a number of our sister societies.

To add some statistics to the above observations, total membership stood at 17,469 on October 1, an increase of 421 over last year.

We had 3,364 abstracts submitted for the Denver Annual Meeting, only one fewer than the record-setting 2000 meeting in Reno, and 6,269 total attendees.

GSA Publications saw much activity this past year. Submissions to Geology are up 30\% over last year. The books division was reorganized, resulting in cost savings and reduction in production time from acceptance to publication. Fourteen volumes are scheduled for 2002, up from seven in 2001. Looking to the future, GSA continues to work with six other societies to develop an electronic journal aggregate.
Education and Outreach programs saw an increase in both the number of participants and sponsorships. GSA named Chris McLelland this year's Subaru Distinguished Earth Science Teacher, and Raphael Sagarin, a scientist with a degree in earth systems and interest in climate change was appointed as the 16th GSA-USGS Congressional Science Fellow. I am also pleased to announce that Gary Lewis from Geoscience Australia has agreed to join GSA as its Education and Outreach director beginning in January.

Building strong, meaningful partnerships is important to GSA's future. To that end, I have established a staff focal point for building effective, meaningful partnerships with others in our earth science community. The number of Associated Societies has grown to 24 with the addition of the International Association of Hydrogeologists-U.S. National Chapter, and the number of Allied Societies stands at five. We continue to develop and renew memoranda of understanding with other societies to strengthen our relationships.

Under the leadership of GSA President Tony Naldrett, two important ad hoc committees were formed, with participation from both staff and members to look at future revenue opportunities and efficiencies in headquarters operation and governance.

GSA has much to be proud of and can look forward with optimism to a bright future as a broad, unifying scientific society that is advancing the geosciences, enhancing the growth of its members, and promoting the geosciences in the service of humankind.

I want to end by thanking you, the GSA members, the Council and Executive Committee, and the GSA Headquarters staff for a most challenging and enjoyable year as your executive director. We could not have accomplished as much without your support and understanding.

\section{GSA Members Invited to Tasmania in 2004}

\begin{abstract}
s part of GSA's strategic plan to
A work with sister geological societies around the world, GSA is a scientific co-host for the17th Australian Geological Convention in beautiful Hobart, Tasmania, February 8-13, 2004. U.S. geoscientists are warmly encouraged to submit ideas for symposia under the theme of "Dynamic Earth: Past, Present and Future." The theme was chosen as a tribute to S. Warren Carey, Foundation Professor of Geology at the University of Tasmania, who died in March 2002. Carey is best known for his influence in having continental drift accepted as reality. Carey was named an Honorary Fellow by GSA in 1979 and received the Career Contribution Award from the GSA Structural Geology and Tectonics Division in 2000.
\end{abstract}

Organizing Committee Chair Pat Quilty is seeking symposia proposals that demonstrate the relevance of geology to the dynamic nature of our planet- the way Earth has evolved, its current state, and how it might be in the future. Each symposium will last a full day and may feature a keynote address, invited and volunteered scientific presentations, and a wrap-up dialogue about future research needs and opportunities for collaboration. Topics of interest currently include: Late Precambrian continental margins; Precambrian banded iron formations and atmospheric evolution; law of the sea; Macquarie Island, Ridge and Alpine fault; deep ocean gateways around the southern hemisphere; mineral and petroleum exploration; groundwater and hydrogeology; en- vironmental issues, including the geology of estuaries; and tectonics.

Suggestions for symposium themes should be sent to Pat Quilty at P.Quilty@utas.edu.au. Please see current information about the convention at www.17thagc.gsa.org.au. Proposal deadline: January 15, 2003. Proposals should include: purpose, focus and scope of the symposium; relevance of the topic; suggested keynote speakers; and your contact information.

Collaboration between Australian and North American geoscientists is encouraged. Call your friends and propose a symposium together! 